\title{
The Impact of Silk Road Economic Belt on Economic Development of the Republic of Kazakhstan: The Case of Khorgos City
}

\author{
Aigul Islamjanova \\ School of Public Affairs, University of Science and Technology of China, \\ Hefei, Anhui, 230026, China. \\ Tel: 86-18656005033 \\ E-mail: kedy_90@mail.ru
}

Issah Iddrisu

School of Public Affairs, University of Science and Technology of China, Hefei, Anhui, 230026, China.

Tel: 86-18755185009

E-mail: issah@mail.ustc.edu.cn

Rathny Suy

School of Public Affairs, University of Science and Technology of China, Hefei, Anhui, 230026, China.

Tel: $86-18755182753$

E-mail: rathny@mail.ustc.edu.cn

Dinara Bekbauova

School of Public Affairs, University of Science and Technology of China, Hefei, Anhui, 230026, China.

Tel: $86-13075566310$

E-mail: 2501673971@qq.com 
Amran Said Suleiman

School of Public Affairs, University of Science and Technology of China, Hefei, Anhui, 230026, China.

Tel: 86-15695656629

E-mail: amransaed@yahoo.com

Received: March 30, 2017 Accepted: May 10, 2017 Published: May 11, 2017

doi: 10.5296/jsss.v4i2.11014 URL: http://doi.org/10.5296/jsss.v4i2.11014

\begin{abstract}
The project "Silk Road Economic Belt" (丝绸之路经济带) launched by the Chinese President Xi Jinping in 2013 at Astana, Kazakhstan is the most single largest economic project in the world. It is the largest in terms of volume and participation of countries. This paper therefore seeks to examine some of the strategic aspects and possible economic impact to the participation of the Republic of Kazakhstan. The study focused on the various aspects of the Silk Road Economic Belt (SREB) which have an influence on economic development of the Republic of Kazakhstan. It also analyzed the implementation of the Silk Road Economic Belt project using Kazakhstan's Khorgos city economic development as a case. The approach used in this paper is based on an analysis of the Silk Road Economic Belt (SREB) in terms of strengths, opportunities and challenges for the future of China-Kazakhstan Economic Cooperation. The project therefore has many in stock for the economy of Kazakhstan when the necessary measures are put in place to tab the opportunities available.
\end{abstract}

Keywords: Kazakhstan, China, Silk Road Economic Belt, Khorgos

\title{
1. Introduction
}

The "One Belt, One Road" (OBOR) initiative is to revive and better the spirit of the old silk road and a step towards realizing the prophecy of the Asian century. The One Belt One Road consists of various mega-projects, but the main two programs are "the Maritime Silk Road" (MSR) and the "Silk Road Economic Belt" (SREB) (Jianmin, 2015)

The Chinese government new initiative aimed at the revival of the Great Silk Road in modern conditions opens new opportunities and prospects for trade-economic and investment cooperation between the countries located along the Silk Road, including the Republic of Kazakhstan. Moreover, for the practical implementation of the initiatives, China is creating new financial development institutions like the Asian Infrastructure Investment Bank (AIIB) and Silk Road Fund. The capital of which will be spent on infrastructure projects. Accordingly, the study considered the role of the "Silk Road Economic Belt" and influence 
on the economic development of the Republic of Kazakhstan. The Republic of Kazakhstan is rich in natural resources which are crucial in achieving the objective of the Silk Road Economic Belt project. In this study, we try to look at the long-term strategy like any other project with its own benefits as there are certain risks and challenges.

The analysis of some aspects of the Silk Road Economic Belt (SREB) which have an influence on economic development of the Republic of Kazakhstan is primarily based on the use of secondary data. This is due to the recent nature of the project. The project is yet to take effect in some participating countries mentioned in the project outline. For this reason, availability of literature on the project is still very scarce. Much of the sources consulted for the work included: academic journal and newspaper articles; secondly, reports published by the international organizations and relevant government bodies; and finally, web-sites of government departments in Kazakhstan. In order to evaluate the implementation of Silk Road Economic Belt in Kazakhstan using the case of Khorgos city, this paper:

- Analyzed the project of SREB and new economic opportunities for Kazakhstan

- Described the main goals of Silk Road Economic Belt in the of case Khorgos

\section{Background of the Study}

\subsection{Economic Overview of Kazakhstan}

After the collapse of the Soviet Union, the Republic of Kazakhstan achieved independence on the 16 December, 1991. It became the ninth largest country in the world with total land area of 2,724,900 sq. km located in the heart of the Eurasia bordering with Russia, China, Kyrgyzstan, Turkmenistan, and Uzbekistan. Nowadays it is dynamically forming up its trade policy, improving its directions and forming new vectors but also one of the lowest population densities globally.

Table 1. Kazakhstan overview

\begin{tabular}{ll}
\hline Kazakhstan & $\mathbf{2 0 1 6}$ \\
\hline Population, million & 17.5 million \\
GDP, current US\$ billion & $\$ 184.5$ billion \\
GDP per capita, current US\$ & $\$ 10,518$ \\
\hline
\end{tabular}

Source: World Bank.

Since 1991, Kazakhstan's economy has experienced many adverse effects, like all other former USSR countries. Reasons included lack of qualified human resources, technologies and necessary international trade skills after its independence from Soviet Union (Achilov, 2016). The failure in output was generally the result of the interruption of oil and natural gas production and exports, loss of subsidies from the Soviet Union, and the exit of skilled Russian technicians, scientists, and managers (Dowling \& Wignaraja, 2006). Due to the close relationship with Russian Federation and China it has become one of the fastest growing 
economies in the region.

In its quest to grow faster, Kazakhstan has become an ambitious country with ambitious plans for its future political and economic development (Linn, 2014). The Republic of Kazakhstan is Central Asia's largest economy, is an upper-middle-income country targeting to join the world's 30 most developed countries by 2050 (Kocak, 2015). Kazakhstan's economy has benefited substantially from increased openness and flexibility over the past decades.

Kazakhstan plays an important role in the world economic processes, because of its significant reserves of natural resources and its location at the intersection of major transcontinental trade and transportation routes. Oil and gas from the first years of independence of Kazakhstan has become the locomotive that has played and continues to play a key role in the growth of the economy of the state (Massakova \& Abdrazakova, 2013). The country is extremely dependent on mining industries and in particular on the oil sector, which accounts for $60 \%$ of total transfers and more than $25 \%$ of GDP. Kazakhstan has huge fossil fuel reserves and large stocks of other minerals and metals, such as uranium, copper and zinc (Bendini, 2013). The country's proven oil reserves are the ninth largest in the world, and hydrocarbon output was nearly $18 \%$ of GDP and about $60 \%$ of exports in 2015 (WorldBank, 2017). Apart from oil, Kazakhstan is the largest producer in the world for the extraction of metals such as iron, chrome, ferro alloys, steel, aluminum which is in great demand abroad.

In recent times, the economy of Kazakhstan is affected by the pressure of global factors. In 2015, there was an adverse impact on Kazakhstan's economy due to a decline in prices for oil and metals on the world market, and falling demand for export products. The country also suffered due to the recession and the slowdown of the economies of Russia, China and Western countries. The decrease in turnover, the drop-in hydrocarbon prices, as well as a significant weakening of the Russian ruble had a negative impact on the economy of Kazakhstan. Additionally, investments in construction, infrastructure development, agriculture and other sectors of economy have become possible only due to significant revenues from oil and gas export in a long-term decline income from export had a negative impact on the non-oil sectors of Kazakh economy (Talantuly, Kenzhekhanovna, \& Zhumabayevna, 2012).

One of the significant aspects for the sustainable economic development of the national economy is foreign trade. At present time, the largest economic partners of Kazakhstan from the Commonwealth of Independent States is Russia, in Europe is Italy and from Asian countries of course main partner is China. According to the World Bank in 2015 the main top 5 Kazakhstan's import partner countries were Russia, China, Germany, USA, and Italy. (Figure 1). 


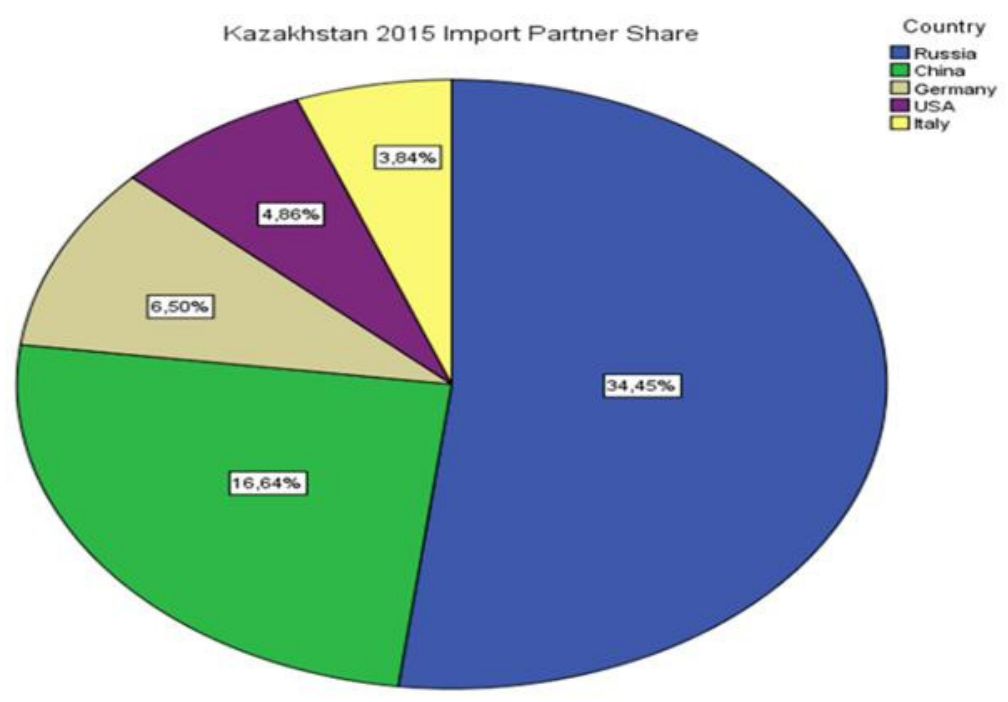

Figure 1. Kazakhstan 2015 Import partner share

Source: World Bank.

Kazakhstan's main import commodities from these countries are: electronics, machinery and mechanical appliances, mineral products, transport equipment, base metals and related products, chemicals, related products, foodstuffs and beverages (Trading Economics, 2017).

After 1991, Kazakhstan had become a significant player in the world energy market due to its substantial oil reserves (Azhgaliyeva, 2014). It is the reason Kazakhstan has an export-oriented economy, highly dependent on shipments of oil and related products and other ferrous metals, copper, aluminum, zinc and uranium (Trading Economics, 2017). The five (5) main export partner countries of Kazakhstan are Italy, China, Netherlands, Russia and France. 


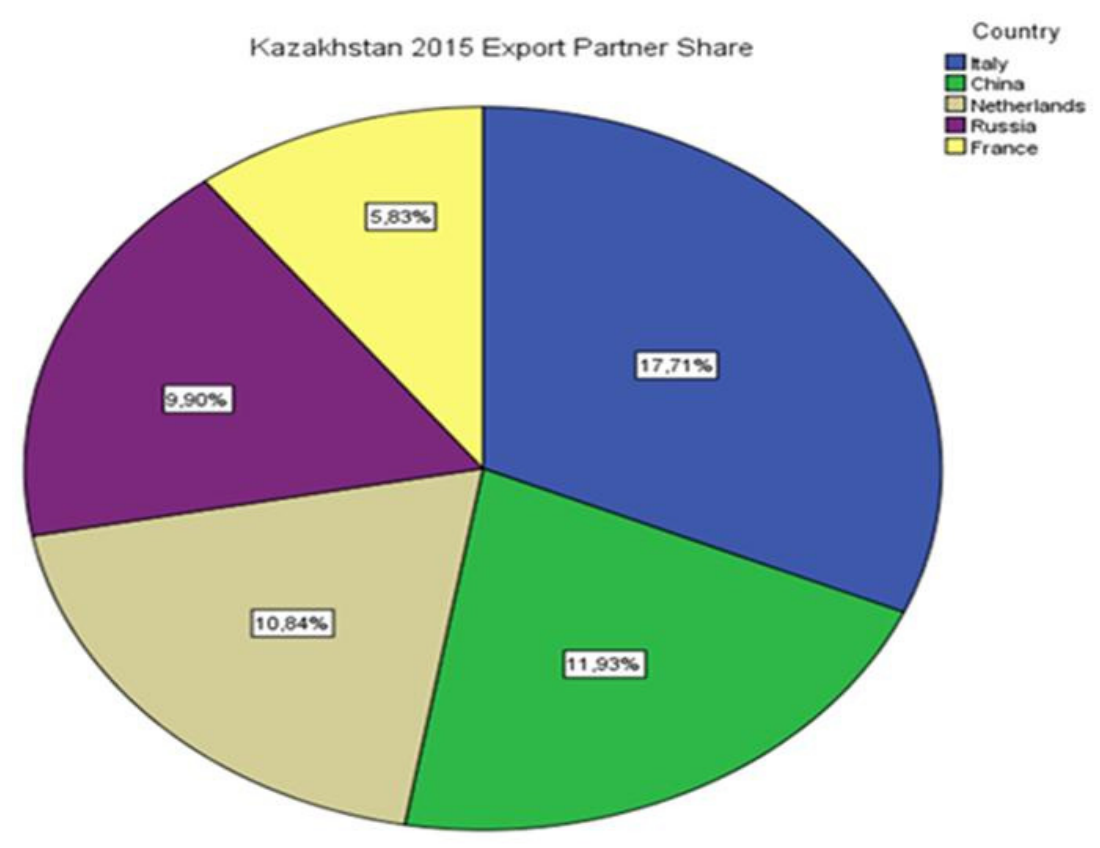

Figure 2. Kazakhstan 2015 Export partner share

Source: World Bank.

The foreign policy of Kazakhstan which is based on multi-vector and balanced relations with all countries of the world, allows the country to increase the national economy, to attract financial resources and to provide external security. For these reasons, Kazakhstan is trying to keep balance between political and economic interests with the main economic partners such as Italy, China, Netherlands, Russia and France (Figure-2).

\subsection{Kazakh-Chinese relations through the Silk Road Economic Belt}

The "Silk Road" used to be the main route of business ties of cultural exchanges and corridor of civilization between Asia and Europe that retained importance for 2,000 years. During the speech on 7 September 2013 at Nazarbayev University in the capital city of Kazakhstan Astana, China's President Xi Jinping coined a new vision for China's relations with Central Asia, calling for the creation of a Silk Road Economic Belt (SREB). The Asian Silk Road was the world's longest economic and trade corridor with the greatest development potential. The intention to revived it with countries along the road makes them poised to gain with the new momentum for economic development and opportunities for sharing the fruits of cooperation (Swaine, 2015). In the view of president Xi Jinping, the formation of the Silk Road Economic Belt (SREB) should include several interrelated steps. They are as follows as in the work of Szczudlik-tatar, (2013):

I) "To strengthen policy communication, which may help "switch on a green light" for joint economic cooperation; II) To strengthen road connections, with the idea to create a mega transport corridor from the Pacific to the Baltic Sea, and from Central Asia to the Indian Ocean, then regularly build a network of transport connections between eastern, western and 
southern Asia; III)To strengthen trade simplification, with a focus on eliminating trade barriers and taking steps to reduce trade and investment expenses; IV)To strengthen monetary cooperation, with special consideration to currency settlements that could decline transaction costs and lessen financial risk while growing economic competitiveness; V)To strengthen people-to-people relations" (Szczudlik-Tatar, 2013).

The Silk Road Economic Belt aims at expanding China's economic connections possibly political influence across much of Eurasia through enormous infrastructure and investment schemes (Zhang, 2015). The initiative of the Silk Road Economic Belt has become not just a concept, it is the largest international project of causing huge economic interest to all countries along the Great Silk Way, including the Republic of Kazakhstan. The implementation of the Chinese initiative "Silk Road Economic Belt" can lead to the shaping of new construction of the world economy around Eurasia, where one of the main link becomes Republic of Kazakhstan. Cooperation with China through the Silk Road Economic Belt would take Kazakhstan to new level of economic cooperation with the other countries as well as integrating with the global market.

Kazakhstan's ties with China have been growing exponentially ever since the two countries formed diplomatic relations in January 3, 1992. Since then, relations between the two countries has grown into a strong friendship, good-neighborliness and mutual respect. Kazakhstan and China are mutually interested in developing a long-term and comprehensive strategic partnership. In October 1993, the President of the Republic of Kazakhstan Nursultan Nazarbayev, made an official visit to China. During the meeting, the two signed their first official document which determined the principles of bilateral relations between the two countries «The Joint Declaration on the Principles of friendly relations between the Republic of Kazakhstan and the People's Republic of China" (National Digital History, 2014). After the signing of this historic bilateral agreement, the significance of the People's Republic of China to the Republic of Kazakhstan became no less than the Russian Federation which signified the importance of China to Kazakhstan.

Since independence import and export trade between Kazakhstan and China has been on a quick increase. In 2016, Kazakhstan's exports to China amounted to $\$ 4.2$ billion or $11.5 \%$ of its total exports and China's exports to Kazakhstan amounted to $\$ 3.7$ billion or $14.6 \%$ of its total imports. (See Table 1). According to the "Trend News Agency" trade turnover between Kazakhstan and China amounted to $\$ 1.313$ billion in January-February 2017, including $\$ 717.553$ million of Kazakhstan's exports and \$595.631 million of Kazakhstan's imports (Kosolapova, 2017). As shown above Figure 1 and Figure 2 China occupies one of the top place in the foreign trade of Kazakhstan (accounting for some $20 \%$ of Kazakh's total trade), and Kazakhstan is China's second largest trading partner in the Commonwealth of Independent States region after Russia (Chan, 2016). China's readiness to invest in Kazakh economy has been the key factor driving continual development in their trade relations. 


\section{Macrothink}

Table 2. Export and import commodities between Kazakhstan and China in 2016

\begin{tabular}{|c|c|c|c|c|}
\hline № & $\begin{array}{l}\text { Top 10 Kazakhstan } \\
\text { Exports commodity to } \\
\text { China }\end{array}$ & Volume & $\begin{array}{lr}\text { Top 10 } & \text { Kazakhstan } \\
\text { Imports } & \text { commodity } \\
\text { from China } & \\
\end{array}$ & Volume \\
\hline 1 & Mineral fuels including oil & $\$ 1$ billion & machinery & $\begin{array}{l}\$ 878.2 \\
\text { million }\end{array}$ \\
\hline 2 & Copper & $\begin{array}{l}\$ 865.3 \\
\text { million }\end{array}$ & Electronic equipment & $\begin{array}{l}\$ 712.2 \\
\text { million }\end{array}$ \\
\hline 3 & Inorganic chemicals & $\begin{array}{l}\$ 827.2 \\
\text { million }\end{array}$ & Iron or steel products & $\begin{array}{l}\$ 331.3 \\
\text { million }\end{array}$ \\
\hline 4 & Iron and steel & $\begin{array}{l}\$ 600.7 \\
\text { million }\end{array}$ & Plastics & $\begin{array}{l}\$ 198.4 \\
\text { million }\end{array}$ \\
\hline 5 & Ores, slag, ash & \$446 million & $\begin{array}{l}\text { Medical, } \\
\text { equipment }\end{array}$ & $\begin{array}{l}\$ 131.5 \\
\text { million }\end{array}$ \\
\hline 6 & Zinc & $\begin{array}{l}\$ 180.1 \\
\text { million }\end{array}$ & Vehicles & $\begin{array}{l}\$ 122.2 \\
\text { million }\end{array}$ \\
\hline 7 & Cereal, milk preparations & $\$ 52.4$ million & Footwear & $\begin{array}{l}\$ 118.9 \\
\text { million }\end{array}$ \\
\hline 8 & $\begin{array}{l}\text { Salt, Sulphur, stone, } \\
\text { cement }\end{array}$ & $\$ 35.7$ million & Iron and steel & $\begin{array}{l}\$ 106.3 \\
\text { million }\end{array}$ \\
\hline 9 & Oil seed & $\$ 31$ million & Rubber & $\$ 68$ million \\
\hline 10 & $\begin{array}{l}\text { Animal/vegetable fats and } \\
\text { oils }\end{array}$ & $\$ 22.8$ million & Toys, games & $\$ 55.8$ million \\
\hline
\end{tabular}

Sources: http://www.worldsrichestcountries.com/top_kazakhstan_exports.html http://www.worldsrichestcountries.com/top_kazakhstan_imports.html

After the collapse of the Soviet Union, Independent Kazakhstan gets new opportunities for cooperation outside of former USSR countries. One of the main target of foreign policy of Kazakhstan had been to attract investment from abroad. One of the possible directions become China as a country which has already made huge investments into Republic of Kazakhstan. It has become a key strategic partner in trade, commerce and diplomacy. The foundation of the relationship remains its economic benefits. Chinese foreign direct investment (FDI) in Kazakhstan is one example. Kazakhstan with a large natural resources and mineral deposits, have become for China premier investment destinations (Mariani, 2013). According to the Kazakh newspaper "The Astana Times" Chinese investment in the economy of Kazakhstan amounted to \$623.9 million between January and September 2016, which is seven times higher than in 2015 placing it as a top source of FDI in Kazakhstan. The main drivers of investment in Kazakhstan have been the oil and government sectors, while the investment ratio in the non-oil tradable sectors has been falling since 2001 (World Bank, 
2005). Today the volume of Chinese FDI in Kazakh economy is very impressive, but most of them also associated with the fuel complex - the production and transportation of oil and natural gas. The reason for China's investment in Kazakhstan is the stable and nearby source of natural resources to fuel its own economic growth. For Kazakhstan, its great chance to diversify its economy and China offers them opportunities to reap tremendous benefits (O’Neill, 2014). Promoting good relations with China gives-Kazakhstan stability on mutual border, which will attract Chinese investment to economy development and China's political and economic development provides a somewhat unique developmental model that Kazakhstan could exploit (Hug \& Zhang, 2010).

Despite Kazakh government efforts to diversify its own economy the country is still dependent on oil exports. Therefore, opportunities and alternatives provided by the Chinese government Silk Road Economic Belt (SREB) initiatives serve the needs and goals of Kazakhstan (Fedorenko, 2013).

The SREB is a framework of win-win cooperation for shared development and wealth, peace and friendship, through enhancing common understanding, trust, and exchanges (Hong, 2016). Republic of Kazakhstan is a landlocked country with significant resources, mostly in the form of oil, gas and mineral holding a great potential for the project SREB as a transit bridge for eastern and western Eurasia. For this reason, Kazakhstan has to revive its historic relevance and become the largest business and transit hub of Central Asian region, a peculiar bridge between Europe and Asia. First of all, Kazakhstan has all the advantages such as a perfect geographical position, secondly, the continuous growth of freight traffic; thirdly, it is the direct access to the markets of Customs Union (CU) countries and has a favorable investment climate. All these factors gives a competitive advantage of the project "Silk Road", which will be based on the implementation of the Russian principle of 5S - speed (скорость), service (сервис), cost (стоимость), safety (сохранность) and stability (стабильность) (Kazlogistics, 2012). The interest of Kazakhstan's participation in the Silk Road Economic Belt project is so obvious. Being in the Trans-Eurasian transport and communication corridor, Kazakhstan may greatly accelerate the process of the modernization of the national economy. It is a great chance to improve infrastructure, trade, investment and transportation. The political leadership of Kazakhstan believes that the project can solve some of the challenges of the country such as upgrading aging highway and railway infrastructure, attracting Foreign Direct Investments (FDI), and boosting trade and economic cooperation.

Since the degree of growth of productive capacity and economic growth depends on investment and investment policy of the state, Kazakhstan is already implementing an ambitious strategic goal of building a competitive economy in the framework of SREB. Kazakhstan has announced his own economic program named "The Path to the Future" (Nurly Zhol) where goals are almost the same with the "One Belt, One Road" intended to develop transportation, infrastructure, energy, small and medium business, international roads from Western China to Western Europe (Aldiyarova, 2016). The government of Kazakhstan has launched an annual US\$3 billion package as part of the economic program "The Path of the Future" (Nurly Zhol) with investment priorities including transport and logistics, utility networks and energy infrastructure to attract FDI (Chan, 2016).

Silk Road Economic Belt (SREB) will primarily take shape along railway lines connecting 


\section{Macrothink}

China to Europe via Central Asia. It will create a diversity of logistical and infrastructure components from shopping complexes, warehouses, regional shopping centers. This transportation infrastructure is a first step towards the creation of a Eurasian "Economic Corridor," which will allow for the growth of the Kazakhstan's economy. The main cargo from China to Europe will be a direct rail route through the Republic of Kazakhstan. Almost every day, thousands of tons of Chinese goods passed by sea from one end of the Eurasian continent to the other but in the framework SREB delivering goods to Europe by rail on average will be 2-3 times faster than by sea, which is a competitive advantage for the transference of goods. The government of Kazakhstan is considering options for the establishment of the territory of the whole complex free economic zones (Koshanov, 2016). It will push the growth and development of the economy of Kazakhstan to achieve its target of becoming a member of the world's main thirty economies. Kazakh government believe that the Chinese huge infrastructure investments will also help the country become more competitive as a transit country for the overland movement of vessels between China and the European Union (EU) (Abazov, 2015). Implementation of the SREB will help Kazakhstan to access seaports from participating countries among the project, also it will help to accelerate and reduce the cost of shipping Kazakh goods to the world markets, to increase the volume of foreign and mutual trade (Idrisov, 2016). SREB project will contribute to increasing economic cooperation and cross-border trade between Kazakhstan and China. Also, bordering with China from West, Kazakh natural resources can be imported to China without being transported through sea ways or external land ways, for the Kazakh perspective China offers a main export market that does not need transport through a third country, diversifying the Kazakh economy away from its dependence on Russia. All of this factors shows that Chinese investment in Kazakhstan is in the interest of both countries (O'Neill, 2014). All these factors prove the importance of the Republic of Kazakhstan in the project of Silk Road Economic Belt.

Chinese initiative presents many opportunities for the economy of Kazakhstan, but there are also some risks and challenges. In one hand, economic cooperation with Russia in the framework of Eurasian Economic Union and Russian influence in the region and in other hand Chinese mega project Silk Road Economic Belt and Kazakh's threat about overly economy dependent to China. For over 26 years after the collapsed of the Soviet Union Russian influence is still too high in the region. Bordering in the north with Russia and in the east with China Kazakhstan should find economic and political balance between the two main powers of the world.

\section{Silk Road Economic Belt through the Khorgos}

After the announcement of the Silk Road Economic Belt (SREB) initiative Kazakhstan began doubling down on its investments in infrastructure, special economic zones, highways, railways, and commercial centers. Investments in the transport and logistics sector, aimed at large-scale modernization of infrastructure of Kazakhstan, changing the architecture of the transport routes of Eurasia and reorienting of global supply chains on routes passing through Khorgos and across Kazakhstan.

In 2010 Kazakhstan and China signed an agreement about founding a Khorgos Special 


\section{$\Lambda$ Macrothink}

Economic Zone (SEZ). Khorgos SEZ includes of logistic zone, industrial zone, and transport and logistics center. SEZ Khorgos is the base of implementation of administrative program "Nurly Zhol -The Path to the Future". In accordance with the decree of the President of Republic of Kazakhstan № 187 dated November 29, 2011, it established special economic zone (SEZ) "Khorgos - Eastern gate" with total area 129,8 hectares which is located in Panfilov district of Almaty region on the border with China. The main objective of dry port "Khorgos Gateway" is to increase export and transit potential of Kazakhstan in the Eurasian region, development of competencies in the field of global logistics, attraction of foreign investments.

Transit is a major source of interest for investors in Khorgos, but not the only one. Distributing from the special economic zone (SEZ) is also attractive, offering as it does the possibility of cutting distribution times, especially with the upcoming commissioning of the "dry port," which will include logistics and industrial zones (Astanacalling, 2015). Being transport and logistics linkage between the Asian-Pacific and European markets the Khorgos East Gate Special Economic Zone (SEZ) on the Kazakhstan-China border works as a storage and transport facility, food production, textile manufacturing, chemical and metal treatment base, which, if successful, should get the ball rolling for similar projects (Smith, 2013). For Khorgos, the project "Silk Road Economic Belt" involves infrastructural development, unification of customs procedures, the removal of all kinds of bureaucratic trade barriers. The government of Kazakhstan intends to attract the attention of more than 50 world branded companies to the Khorgos SEZ in order to contribute to the manufacturing sector of the country (Parkhomchik, Simsek, Akhmetkaliyeva, \& Canaltay, 2015).

Khorgos is dry port on the border with Kazakhstan, will be the starting point of the land route of the New Silk Road in China (Kaczmarski, 2015). China plans to turn Khorgos city into a powerful international logistics hub on the Silk Road for the development of new trade and transport links between China, Central Asia, and Europe. It will be a great opportunity for the Republic of Kazakhstan to promote the development of its transport and logistics potential in the region also it will help to attract investment to the region. Khorgos city will complement existing transportation projects and afford an opportunity to realize the potential of landlocked countries. For the Chinese authorities, Khorgos is a city connecting East and West, also a good opportunity for the project Silk Road Economic Belt, which will connect China with Central Asia and Europe through the transport routes, trade, financial flows, and cultural exchange. Over the past five years, the transit of goods from China to Europe via the Khorgos Gateway port has increased by 17 times. The increase began when container trains started shipping electronics of such leading brands as Hewlett Packard, DB Schenker, Toyota, FESCO and BRAVIS (Sultangaliyeva 2016). Volume of cargo handling in the special economic zone 'Khorgos - East Gate' will total more than four million tons per year. This level is planned to be reached by 2020 (Rakhmetov, 2016). Features of Khorgos-East Gate as follow:

- realization of warehousing and care activities for transportation;

- working in multi-modal transport, connecting the port with rail and road routes;

- $\quad$ service high consequence risky goods cargo demanding temperature; 
- $\quad$ perspective of the airport

The SEZ has several facilities, including the International Center for Boundary Cooperation (ICBC), a dry port, logistics and industrial zones, ready connection with the Zhetygen-Khorgos Railway and West Europe-West China Highway. The possibility of direct access to the port of Aktau and a package of attractive fiscal benefits, including exemption from import tariffs, land tax, property tax and value-added tax (Chan, 2016).

ICBC "Khorgos" is a company with absolute contribution of the state, created in the framework of agreements between the government of Kazakhstan and the government of China to establish the International center of boundary cooperation "Khorgos" on the Kazakh-Chinese border in the Panfilov district of Almaty region.

Table 3. International Center for Boundary Cooperation (ICBC) Khorgos

ICBC Khorgos features ICBC Khorgos benefits

Commercial talks, presentation and sale of Common Kazakh-Chinese territory of 560 ha goods

Hotels and restaurants, the infrastructure for Visa-free presence for 30 days commercial services;

financial services;

Transport and terminal operations;

Free moving on ICBC Khorgos territory for individuals, goods and transport

Organization of different forms of regional

Prepared infrastructure publicly funded

and international meetings on the subject of

Deployment of the separate Law «On Special economy and trade and other species

Economic Zone of ICBC

Offers privileges and preferences for investors.

Source: http://www.kinno.fi/sites/default/files/eng_ktz_express_finland_march_2017_09.03.2017-3.pdf

ICBC Khorgos is poised to become a leading center for the Belt and Road network of combined dry and sea ports, special economic zones, new cities, and free trade zones that cover 65 countries between China and Europe (Shepard, 2016). The center is a complex (center) trade, economic and investment cooperation, consisting of the Kazakh and Chinese parts, located on the border of the neighboring territories of the two States. Establishment of the Center will promote intensive development of Kazakh economy in the Almaty area, the development and enhancement of transport, engineering and tourism infrastructure, increased traffic, the emergence of new places of employment, increase living standards of the resident population. The development of trade and transport links in the region is sufficient in order to satisfy the interests and benefit of both countries. Khorgos will play a dynamic role in the creation of the SREB. To mitigate the transportation pressure at Alashankou, the Jinghe-Khorgas Railway has been interconnected with Kazakhstan railways, and its role in helping regional economic collaboration and cultural relations between China and Central 
Asian republics. Despite its current problems, the Khorgas port-of-entry railway station has huge potential and is bound to develop into an international logistics hub, integrating passenger and cargo transport, warehousing, and e-commerce (He, 2016).

\section{Conclusion}

Republic of Kazakhstan approved the strategic initiative of president Xi Jinping on the construction of the Silk Road Economic Belt. It is also willing to strengthen support in areas such as economics, communications and cultural-humanitarian interaction. In considering all the inter-connected potential benefits of the project, the study can conclude that such large-scale and long-term project has certain benefits for Kazakhstan as a potential participant. This is also based on the possibility of participation subject to certain conditions. The interest of China's investment in Kazakhstan is driven by a big amount of energy resources such as oil, uranium, and natural gas. The location of Kazakhstan is vital for the area of transportation projects, especially a planned high-speed rail line that would run from China to Europe via Kazakhstan. Both countries have mutual interest in different spheres. The project Silk Road Economic Belt is an opportunity to promote mutual interests and multilateral relationships between Kazakhstan and China. This relationship started long before the initiation of the Silk Road Economic Belt project.

The Chinese initiative of the Silk Road Economic Belt is still at the early stage of development. Analyzing this baby project of the Chinese president with its impact on Khorgos city cannot be over emphasized. This huge project is in no doubt has a lot of advantages and as well has its repercussions on every country that will be involved. Looking at the literature so far Khorgos city turns to benefit more due to its strategic location along the project course. The project therefore has enormous impact on the economy of Khorgos and Kazakhstan in general. Given the numerous auxiliary activities to be carried out during the cause of the cooperation between China and other countries including Republic of Kazakhstan, there will be an economic growth and development in Kazakhstan. In the implementation of the "One belt and one road" project, China in its might will want to demonstrate how it is actively involved in the world economy and as well making an impact in shaping it. On the other hand, China needs new political concepts that are able to compete with the West in order to expand their international influence.

\section{Acknowledgement}

The authors would like to thank the anonymous reviewers and the academic editor of this journal for the invaluable comments and suggestions which have substantially improved the manuscript. I also would like to acknowledge to CSC scholarship to support my study at University of Science and Technology of China in Hefei.

\section{References}

Abazov, R. (2015). Kazakhstan's revival of the Silk Road Initiative: the challenges ahead Analytical Articles.

Achilov, N. (2016). Developing Export Potential in Kazakhstan: An Overview of Key 
Theories and Recommendations for Policy Development. Journal of Global Economics, 4(4), $1-3$.

Aldiyarova, A. (2016). Legal matters of the modern silk road between the people's Republic of China and the Republic of Kazakhstan. Nnamdi Azikiwe University Journal of International Law and Jurisprudence, 7, 170-175.

Astanacalling. (2015). Kazakhstan, UN Actively Grow 23-Year Productive Relationship. (396), 1-15.

Azhgaliyeva, D. (2014). The effect of fiscal policy on oil revenue fund: The case of Kazakhstan. Journal of Eurasian Studies, 5(2), 157-183. https://doi.org/10.1016/j.euras.2014.05.001

Bendini, R. (2013). Kazakhstan: Selected trade and economic issues Retrieved from http://www.europarl.europa.eu/RegData/etudes/briefing_note/join/2013/522303/EXPO-INTA _SP(2013)522303_EN.pdf

Chan, L. (2016). Kazakhstan: A Modern Silk Road Partner. 1-11.

Dowling, M., \& Wignaraja, G. (2006). Central Asia after fifteen years of transition: Growth, regional cooperation, and policy choices. Asian Development Bank (ADB), 3, 1-26.

Fedorenko, V. (2013). The new Silk road initiatives in Central Asia. Rethink Institute, 10, $1-36$.

He, H. (2016). Key Challenges and Countermeasures with Railway Accessibility along the Silk Road. Engineering, 2(3), 288-291. https://doi.org/10.1016/J.ENG.2016.03.017

Hong, P. (2016). Jointly Building the'Belt and Road'towards the Sustainable Development Goals. United Nations Department of Economic and Social Affairs (DESA), 1-19.

Hug, A., \& Zhang, F. (2010). Kazakhstan at Crossroads: Kazakhstan and the World. The Foreign Policy Centre, 1-11.

Idrisov, A. (2016). Silk Road Economic Belt and Eurasian integration: competition or new opportunities? [Экономический пояс Шелкового пути и евразийская интеграция: конкуренция или новые возможности?]. Bridges, 5, 4-11.

Jianmin, W. (2015). One Belt and One Road, Far-reaching Initiative. China-US Focus Digest.

Kazlogistics (Producer). (2012). Economic corridor "New Silk Road" Retrieved from http://www.kazlogistics.kz/ru/media_center/interview/detail.php?id=577

Kocak, K. A. (2015). Kazakhstan: Economic situation. European Parliamentary Research Service Retrieved from http://www.europarl.europa.eu/thinktank.

Koshanov, A. (2016). One Belt One Road and prospects of formation of the Eurasian economic community. [Единый Пояс Щелкового Пути и перспективы формирования объединенного Евразийского экономического сообщества]. Society and Economy, 2016(4). 
Kosolapova, E. (2017). Kazakhstan's main trade partners: Russia, EU and China [Press release]. Retrieved from http://en.trend.az/casia/kazakhstan/2743461.html

Linn, J. F. (2014). Kazakhstan 2050 Exploring an Ambitious Vision. Global Journal of Emerging Market Economies, 6(3), 283-300. https://doi.org/10.1177/0974910114540718

Mariani, B. (2013). China's role and interests in Central Asia. Saferworld, 1-21.

Massakova, S., \& Abdrazakova, A. (2013). Industrial policy: problems and task in gas and oil sector of national economy. International Journal of Economics and Finance Studies, 5(1), 310-321.

National Digital History. (2014). Kazakhstan-Chinese relations at the present stage. Retrieved from http://e-history.kz/en/contents/view/2162

O'Neill, D. C. (2014). Risky business: The political economy of Chinese investment in Kazakhstan. Journal of Eurasian Studies, 5(2), 145-156. https://doi.org/10.1016/j.euras.2014.05.007

Parkhomchik, L., Simsek, H., Akhmetkaliyeva, S., \& Canaltay, C. (2015). The geo-economic importance of the Khorgos gateway: current developments. Eurasian Research Institue, 3(43), $1-2$.

Rakhmetov, N. (2016). Volume of processed cargo at Khorgos-East Gate to exceed four million tons by 2020. Retrieved from http://kazakh-tv.kz/en/view/news_kazakhstan/page_161779_volume-of-processed-cargo-at-k horgos-east-gate-to-exceed-four-million-tons-by-2020

Shepard, W. (2016). An Inside Look At China And Kazakhstan's 'Absurd' Cross-Border Free Trade Zone. Retrieved from https://www.forbes.com/sites/wadeshepard/2016/07/26/an-inside-look-at-icbc-khorgos-chinaand-kazakhstans-cross-border-free-trade-zone/

Smith, M. (2013). The Kazakhstan opportunity. Expert Opinion, 48-49.

Sultangaliyeva, A. (2016). Kazakhstan and its neighbors: opportunities and limitations. The Institute of World Economics and Politics under the Foundation of the First President of Kazakhstan Leader of the Nation, 1-72.

Swaine, M. D. (2015). Chinese views and commentary on the 'One Belt, One Road'initiative. China Leadership Monitor, 47, 1-24.

Szczudlik-Tatar, J. (2013). China's New Silk road diplomacy. The Polish Institute of International Affairs, 34(82), 1-8.

Talantuly, N. E., Kenzhekhanovna, N. M., \& Zhumabayevna, D. M. (2012). Modern Foreign Trade Activities of Kazakhstan Republic. World Applied Sciences Journal, 18(111-117), 1-7.

Trading Economics. (2017). Kazakhstan Imports 1998-2017. Retrieved from http://www.tradingeconomics.com/kazakhstan/imports 


\section{Macrothink}

Journal of Social Science Studies

ISSN 2329-9150

2017, Vol. 4, No. 2

World Bank. (2005). Republic of Kazakhstan Country Economic Memorandum (30852-KZ). Retrieved from

World Bank. (2017). Kazakhstan: overview. https://www.worldbank.org/en/country/kazakhstan/overview

Zhang, H. (2015). Building the silk road economic belt: Challenges in Central Asia. Cambridge Journal of China, 17-35.

\section{Copyright Disclaimer}

Copyright for this article is retained by the author(s), with first publication rights granted to the journal.

This is an open-access article distributed under the terms and conditions of the Creative Commons Attribution license (http://creativecommons.org/licenses/by/3.0/). 